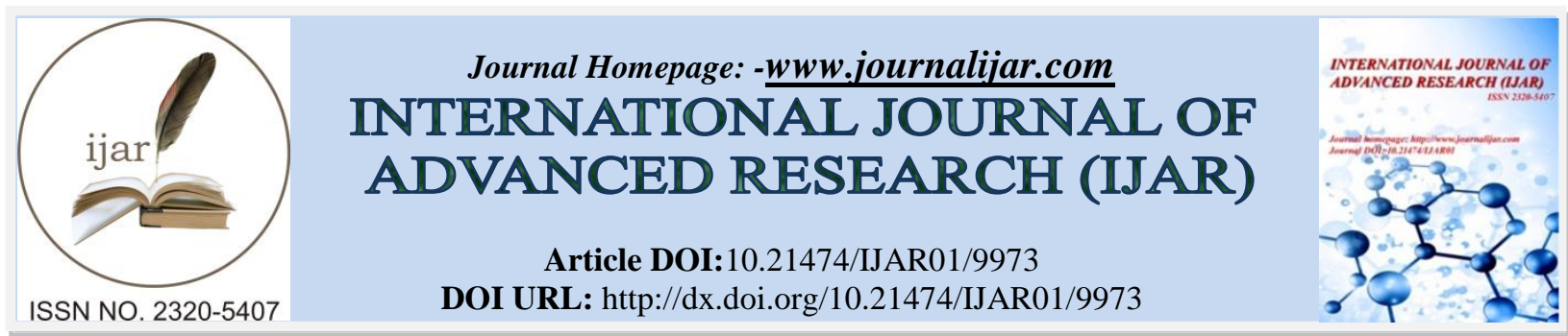

RESEARCH ARTICLE

\title{
ASSESSMENT OF NUTRITIONAL QUALITIES AND ACCEPTABILITY OF BREADS PRODUCED WITH MORINGA OLEIFERA POD FLOUR.
}

\section{Dimelu, Ifeoma Ngozi ${ }^{1}$, Eze, Emmanuel Ikechukwu ${ }^{2}$, Chukwuone, Amaka Adaobi ${ }^{1}$ and Ndubuaku, Uchenna Mabel $^{2}$.}

1. Department of Home Economics and Hospitality Management Education, Faculty of Vocational Technical Education, University of Nigeria, Nsukka.

2. Department of Crop Science, Faculty of Agriculture, University of Nigeria, Nsukka.

\section{Manuscript Info}

..........................

Manuscript History

Received: 05 September 2019

Final Accepted: 07 October 2019

Published: November 2019

Key words:-

Nutritional, Qualities, bread, Moringa oleifera pod.

\section{Abstract}

An in-vitro assay was carried out to ascertain the effect of addition of dry Moringa oleifera pod flour on the quality of composite bread, which hitherto had constituted an important dietary intake of many people in Nigeria. M. oleifera pod was processed into flour and mixed with composite flour for bread production. Four samples of bread were produced and labelled Samples $20 \mathrm{~g}, 40 \mathrm{~g}, 60 \mathrm{~g}$ and Control. The control contained $100 \%$ wheat flour, while Sample $20 \mathrm{~g}$ to $60 \mathrm{~g}$ had dry M. oleifera pod flours added in an increasing order of $20 \%, 40 \%$ and $60 \%$. The nutritional properties of the bread loaves were evaluated and the result varied significantly with increasing levels of $M$. oleifera pod flours. The proximate composition of bread fortified with $M$. oleifera pod flours showed that the moisture content decreased significantly $(p<0.05)$ with increased $M$. oleifera pod flours varying from $22.4 \%$ to $32.6 \%$ while that of protein contents increased from $2.84 \%$ to $3.06 \%$. The fat contents of the bread samples did not differ significantly $(p<0.05)$ with increase in $M$. oleifera pod flours while the carbohydrate contents of the bread samples increased significantly $(p<0.05)$ with increase in $M$. oleifera pod flours. The mineral, phytochemical and vitamin contents increased with the increase in the addition of M. oleifera pod flours. The result of the sensory properties showed that the flavour, texture, mouth feel, colour and overall acceptability of each product was significantly $(p<0.05)$ enhanced by the addition of $M$. oleifera pod flour. The $100 \%$ wheat bread recorded the lowest scores in all the major parameters evaluated while all the other samples were well accepted. Overall, there was an increase in the values of acceptability, appearance and flavour of the bread samples with increasing levels of M. oleifera pod flours.

Copy Right, IJAR, 2019,. All rights reserved.

\section{Introduction:-}

Bread is a prominent staple food prepared from dough of flour and water. In many parts of the world, bread is made from the flour of wheat species. The wheat-flour dough is normally, cultured with yeast, which is the rising agent (Dewettinck et al., 2008). In Nigeria, however, bread is produced from other flour sources such as maize and

Corresponding Author:- Eze, Emmanuel Ikechukwu.

Address:-Department of Crop Science, Faculty of Agriculture, University of Nigeria, Nsukka. 
cassava because of the paucity of wheat flour. These flours used in Nigeria for bread production have poor nutrient compositions and have affected negatively the nutritional status of a great number of Nigerians. This is because bread is highly consumed in Nigeria by many people owing to its quick way of production and the low cost at which it is sold to the consumer (David, 2006). Thus, in Nigeria, a good number of people who consume bread are deficient in one micronutrient or the other. These micronutrient deficiencies cause intellectual and developmental disabilities in many people and can be prevented (Hettiarachchi et al., 2006).

One of the ways of preventing these deficiencies and disabilities is to develop a bread production protocol with available plant materials that are rich in micronutrients. At present, plant like Moringa oleifera that is sustainable and has been found to be rich in both macro and micro-nutrients (Anwar et al., 2007), could be harnessed for this mission. Kalibbala et al. (2009) reported $M$. oleifera to be widely cultivated, rich in nutrients and even phytochemicals. The presence of phytochemicals such as flavonoids and phenol in M. oleifera can produce both antimicrobial and antioxidant effects (Kalibbala et al., 2009). The antioxidant effects of M. oleifera will take care of some of the additives used in commercial breads production as bread improvers and dough conditioners to improve the texture and volume but facilitate oxidation in human cells (Tenbergen, 1999). Thus, the use of M. oleifera pod in bread production done in this research will not only place millions of bread consumers on adequate nutrition but also on safe and sustainable diet.

\section{Materials and Methods:- \\ Sample Sources}

The moringa pod was obtained from the Department of Crop Science, University of Nigeria, Nsukka in Enugu State, Nigeria. The freshly harvested moringa pod was oven dried at a temperature of $60{ }^{\circ} \mathrm{C}$ for two days. This was ground to a fine particle size using Thomas-Wily Laboratory Mill (USA, Model no: 4).

\section{Preparation of Bread Samples}

The preparation of bread with dry Moringa pod flour was carried out as described by Campbell et al. (2001), except that the dry moringa pod flour were used to replace milk. The recipes used were $500 \mathrm{~g}$ wheat flour, $125 \mathrm{~g}$ butter, 12 $\mathrm{g}$ yeast, $60 \mathrm{~g}$ sugar, $125 \mathrm{~g}$ liquid, one teaspoonful of salt and dry moringa pod flour at $0 \mathrm{~g}, 20 \mathrm{~g}$, $40 \mathrm{~g}$ and $60 \mathrm{~g}$. The baking of the Moringa pod bread was carried out in the Bakery Unit of the Department of Home Economics Education, University of Nigeria, Nsukka using a hot air oven at a temperature of $220{ }^{\circ} \mathrm{C}$ for 20 minutes.

\section{Proximate Analysis}

Proximate analysis involved the determination of ash, crude protein, crude fat, crude fibre, moisture and carbohydrate contents. These were carried out using the standard method of analysis by the Association of Official Analytical Chemists (AOAC, 2000).

\section{Determination of Vitamins}

The thiamin and the riboflavincontents of the bread were determined as described by Onwuka (2005) while the provitamin A was determined as described by Jakkutowicz et al. (1977). The analysis of vitamin C and vitamin E were carried outas described by Olokodona (2005) and Pearson (1976), respectively.

\section{Mineral Determination}

Phosphorus, calcium copper, zinc and iron were determined by directly reading in the Atomic absorption spectrophotometer (Model number AA-7000, ROM Version 1.01 and Serial number A30664700709) as described by Pearson (1976).

\section{Determination of the Phytochemical Constituents}

The phytochemicals determined in the bread samples produced were alkaloids, flavonoids, tannin, tepernoid and saponnins.

\section{Determination of alkaloids}

The alkaloids present in the bread were determined using the method described by Harbone (1973). Five gram of bread was measured into $100 \mathrm{ml}$ beaker then $50 \mathrm{ml}$ of $10 \%$ acetic acid in ethanol was introduced into it and covered to stand for 4 hours after which it was filtered. Thereafter, $10 \mathrm{ml}$ of ammonium hydroxide was introduced into the filtrate to precipitate the alkaloids. The precipitate was filtered, weighed, dried and the percentage alkaloid calculated as shown below. 
Alkaloid $(\%)=\frac{\text { [weight of the filter papert Alksloid] }- \text { [weight of filter paper only? }}{\text { Wweight of ground sample used. }} \frac{100}{1}$

\section{Determination of Flavonoids}

Flavonoids were determined using the method described by Boham and Kocipal (1974). Five gram of the bread was measured into flask and the flavonoids were extracted repeatedly with $100 \mathrm{ml}$ of $80 \%$ aqueous methanol at room temperature. Thereafter, it was filtered with Whatman filter paper No $43(125 \mathrm{~mm})$ and the filtrate transferred into weighed beaker and evaporated to dryness to get the weight of the flavonoids. The percentage flavonoids were calculated thus:

Flavonoid $(\%)=\frac{\text { [weight of beaker }+ \text { flawonoid] }- \text { [weight of beaker only }]}{\text { Weight of sample used }} \times \frac{100}{1}$

\section{Determination of Tannins}

Tannin was determined as described by Pearson (1976). One gram of the sample was weighed and $10.0 \mathrm{ml}$ of distilled water added. This was shaken at $5 \mathrm{~min}$ interval for $30 \mathrm{~min}$. The solution of the sample was centrifuged or filtered to get the extract. Then, $2.5 \mathrm{ml}$ of the supernatant was transferred into a test-tube. This was added $1.0 \mathrm{ml}$ Folin-Denis reagent, followed by $2.5 \mathrm{ml}$ of saturated $\mathrm{Na}_{2} \mathrm{CO}_{3}$ solution. About $2.5 \mathrm{ml}$ of standard tannic acid solution and blank were also prepared alongside with the test sample and the absorbance read after 90 min of incubation at room temperature. The percentage tannin was calculated thus:

$\%$ Tannin $=$ An/As $\times$ C $\times \frac{100}{W} \times \frac{v f}{v a}$

where $\mathrm{An}=$ absorbance of test sample

As $=$ absorbance of standard solution

$\mathrm{C}=$ Conc of standard solution

$\mathrm{W}=$ weight of sample used

$\mathrm{Vf}=$ total volume of extract

$\mathrm{Va}=$ volume of extract analyzed.

\section{Determination of the Organoleptic Properties of the Formulated Breads}

The sensory evaluation was carried out as described by Ihekoronye and Ngoddy (1985) using a twenty-man panel from the Department of Home Economics Education, University of Nigeria Nsukka. The members of the panel were instructed to indicate their preference of the test products. A nine-point hedonic scale, where 9 was the highest score while 1 was the lowest score for each characteristics such as flavour, texture, mouth feel, colour and overall acceptability of each product was selected for sensory evaluation of the products as described by Iwe (2002). The interpretation of the panelists' response showed the level of acceptability of the products.

\section{Statistical Analysis:-}

The data obtained were subjected to analysis of variance (ANOVA) using GenStat Release 10.3 DE (2011) statistical software.

\section{Results and Discussion:-}

The proximate compositions of the formulated breads are shown in Table 1. The moisture content of the bread produced with $M$. oleifera pod flours significantly $(p<0.05)$ decreased with increase in the concentration of the Moringa pod flour at $20 \mathrm{~g}, 40 \mathrm{~g}$ and $60 \mathrm{~g}$. This could be attributed to capability of the dry M. oleifera pod flours to absorb the free moisture in the bread. Similar result was observed by Mbaeyi and Anyanwu (2010) where dry mango pulp decreased moisture content of yoghurt formulated with solar dried bush mango pulp. The moisture content of the control sample which had no M. oleifera pod flour was therefore significantly $(\mathrm{p}<0.05)$ higher. The protein content of the bread produced with $M$. oleifera pod flours significantly $(p<0.05)$ increased with increase in the concentration of the Moringa pod flour. This shows that the protein of bread can be complemented by that of Moringa pod flour. Harnessing complementary sources of protein in recipe development in meal preparation have been highly recommended for handling protein malnutrition (Healthy Water Living, 2007)

The ash content of the bread samples increased with the increase in the concentration of the M. oleifera pod flours used in bread formulation. This showed that the mineral composition of the bread increased with the addition of the M. oleifera pod flours since ash content is a measure of the total amount of minerals present within a food. There 
was no difference in fibre contents of the bread samples produced with $M$. oleifera pod flours. This agreed with the findings of Awaziem (2007) that fibre contents of locally produced foods hardly differ from their counterpart sample with varying compositions. The fat content of the bread produced with $M$. oleifera pod flours significantly $(\mathrm{p}<0.05)$ decreased with increase in the concentration of the Moringa pod flour. This shows that Moringa pod flour can lower the fat contents of bread samples. The bread produced with the highest concentration of M. oleifera pod flours is therefore low in calories and fat. Foods that contain low fat and oil are therefore good source of food supplement for patients with cardiac problems or at risks with lipid induced disorder (Egwim et al., 2011).

Table 1:-The effect of the M. oleifera pod flours on the proximate compositions of the formulated bread

\begin{tabular}{|l|l|l|l|l|l|l|}
\hline Samples & Moisture\% & Ash \% & Fat \% & Fibre \% & Protein \% & Carbohydrate \% \\
\hline $20 \mathrm{~g}$ & 32.6 & 1.0 & 2.70 & 0.5 & 2.84 & 61.36 \\
\hline $40 \mathrm{~g}$ & 32.0 & 1.2 & 1.95 & 0.5 & 2.91 & 62.44 \\
\hline $60 \mathrm{~g}$ & 22.4 & 1.2 & 1.75 & 0.5 & 3.06 & 71.09 \\
\hline Control & 33.5 & 0.95 & 1.65 & 0.1 & 2.63 & 60.06 \\
\hline LSD $(\mathrm{p}<0.05)$ & 1.88 & 0.24 & 0.34 & 0.23 & 1.88 & 1.90 \\
\hline
\end{tabular}

The mineral contents of the bread samples are presented in Table 2. The bread contained variable amount of macronutrients $(\mathrm{Ca}, \mathrm{Mg}$ and $\mathrm{P})$ and trace elements $(\mathrm{Fe}, \mathrm{Zn}$ and $\mathrm{Cu}$ ). Bread samples containing $40 \mathrm{~g}$ and $60 \mathrm{~g}$ of M. oleifera pod flour were significantly $(p<0.05)$ higher than the control (sample without Moringa pod flour) in magnesium and calcium compositions. Consumption of this type of bread containing adequate magnesium and calcium will be beneficial to both infant and aging population because of the utilization of these minerals in bone formation (Touyz, 2003). Breads rich in phosphorus are of importance in the synthesis of adenosine triphosphate (ATP). All the bread samples formulated with Moringa pod flour were significantly $(p<0.05)$ higher than the control in iron concentration. The high contents of iron can be attributed to high level of iron in Moringa pod. Aslam et al. (2005) had reported moringa pod to be rich in iron content. Iron is very useful in haemoglobin synthesis in the body (American Society of Hematology, 2019). Since iron deficiency is very common among people who consume foods low in iron such as bread, fortifying breads with Moringa pod flour could serve as an alternative to iron supplements which are costly and even scarce in many Africa settings like Nigeria. Thus, this type of breads high in iron can be harnessed for treatment of iron deficiency anemia. National Heart, Lung, and Blood Institute (2019) also reported that eating iron supplements or intravenous iron therapy could be effective in the treatment of moderate irondeficiency anemia. The bread sample formulated with $60 \mathrm{~g}$ moringa pod flour was significantly $(p<0.05)$ higher than the control in copper concentration. This shows that bread formulation with $60 \mathrm{~g}$ of Moringa pod flour could serve well as iron supplements, since the association of copper and iron in foods had always been useful in enhancing iron metabolism and absorption in human body system (Collins et al., 2010). The concentration of zinc in the bread samples increased significantly $(p<0.05)$ with the addition of the Moringa pod flour. The high contents of zinc in the formulated breads could be attributed to high level zinc in Moringa pod (Aslam et al., 2005). Since zinc deficiency is one of the serious problems of micronutrient deficiencies in the developing countries, production of cheap and commonly consumed foods such as breads rich in zinc will go a long way to ameliorate the negative effects in the lives of millions of people.

Table 2:-The effect of the $M$. oleifera pod flours on the mineral compositions of the formulated bread in $\mathrm{g} / \mathrm{Kg}$

\begin{tabular}{|l|l|l|l|l|l|l|}
\hline Samples & $\mathrm{Fe}$ & $\mathrm{Mg}$ & $\mathrm{Ca}$ & $\mathrm{Zn}$ & $\mathrm{Cu}$ & $\mathrm{P}$ \\
\hline $20 \mathrm{~g}$ & 115.8 & 0.5 & 0.06 & 4.18 & 1.93 & 1.00 \\
\hline $40 \mathrm{~g}$ & 231.6 & 1.02 & 1.34 & 8.36 & 3.86 & 2.01 \\
\hline $60 \mathrm{~g}$ & 347.4 & 1.52 & 2.0 & 12.54 & 5.80 & 3.04 \\
\hline Control & 20.06 & 0.1 & 0.03 & 1.61 & 0.05 & 0.25 \\
\hline LSD $(\mathrm{p}<0.05)$ & 1.88 & 0.54 & 1.00 & 1.67 & 1.33 & 1.34 \\
\hline
\end{tabular}

The phytochemical contents of the formulated bread samples increased with the addition of the dry M. oleifera pod flour on the composite bread as represented in Table 3. The percentage alkaloids present in the bread samples increased proportionally with the increase in the M. oleifera pod flour. Plant alkaloids, like that of M. oleifera pod, have high medicinal values and can produce sedative and analgesic effects. Eze and Orjioke (2010) reported that plant alkaloids are useful raw material for the production of pain relieving drugs. Breads produced from M. oleifera pod flour can therefore double as a source of nutrients and a pain reliever when eaten. This will be beneficial to thousands of rural and urban poor dwellers in Nigeria who can only afford to eat breads with water after engaging in 
hard manual labours. The percentage flavonoid contents of the bread samples fortified with $M$. oleifera pod flour also increased with the increase in the concentration of the pod flour. Flavonoids are highly rich in antioxidants (Pietta, 2000) and could play a beneficial role in the reduction of oxidative stress (Botella et al., 2004). Since oxidative stress is the primary cause of aging and several degenerative diseases, such as atherosclerosis, cardiovascular disease, type II diabetes and cancer (Tsao, 2010), bread produced from M. oleifera pod flour can salvage millions of Nigerians who eat bread with carbonated drinks and other junk foods by its antioxidant actions. The tannin contents of all theformulated bread samples were low. Although tannins can inhibit protein absorption in the gastric system (Osagie, 1998), moderate levels of tannins in foods have healing effects in man. Tsao (2010) reported that little quantity of tannins in foods could have a therapeutic effect in human beings. Besides, the values of tannins in the bread samples are within the safe level for human consumption (Okonwu and Ugiomoh, 2015) and will, therefore, have no influence on the protein absorption in the gastric system. Therefore, the presence of the medicinal phytochemicals such as alkaloid, flavonoid and saponnin in the formulated bread samples might confer high medicinal values to the bread samples.

Table 3:-The effect of the M. oleifera pod flours on the percentage phytochemical compositions of the formulated bread

\begin{tabular}{|l|l|l|l|l|l|}
\hline Samples & Alkaloid & Flavonoid & Tannin & Tepernoid & Saponin \\
\hline $20 \mathrm{~g}$ & 0.62 & 1.04 & 0.007 & 0.94 & 0.29 \\
\hline $40 \mathrm{~g}$ & 1.24 & 2.08 & 0.009 & 1.88 & 0.61 \\
\hline $60 \mathrm{~g}$ & 1.86 & 3.12 & 0.011 & 2.82 & 0.89 \\
\hline Control & 0.01 & 0.13 & 0.001 & 0.03 & 0.07 \\
\hline LSD $(\mathrm{p}<0.05)$ & 0.14 & 1.33 & 0.004 & 0.034 & 0.13 \\
\hline
\end{tabular}

The vitamin composition of the formulated bread samples increased with the addition of the dry M. oleifera pod flour on the composite bread except vitamin $\mathrm{B}_{2}$ (Table 4). The bread samples fortified with Moringa oleifera pod flour contained high levels of B-carotene, vitamins $\mathrm{B}_{1}, \mathrm{C}$ and $\mathrm{E}$ than the control. This shows that addition of the dry M. oleifera pod flour to bread can supplement its vitamin contents and make it delicious. Stanley et al. (2011) observed that foods with multivitamins are always delicious and provide good tastes, flavor and texture. Since, the bread samples produced with $M$. oleifera pod flours were significantly $(p<0.05)$ higher than the control in all the vitamins analyzed, except in vitamin $\mathrm{B}_{2}$, it could be deduced that the recipe for conventional bread production contain vitamin $\mathrm{B}_{2}$ which was depleted with the addition of $M$. oleifera pod flours. Vitamins $\mathrm{C}$ and $\mathrm{E}$ as well as the B-carotene were significantly $(p<0.05)$ higher in the fortified bread samples than the control and they have antioxidant actions. Okwulehie and Odunze (2004) reported foods high in these vitamins to have high antioxidative activity in human body system.

Table 4:-The effect of the $M$. oleifera pod flours on the vitamin compositions of the formulated bread

\begin{tabular}{|l|l|l|l|l|l|}
\hline Samples & $\begin{array}{l}\text { Vitamin } \mathrm{B}_{1} \\
(\mathrm{mg} / 100 \mathrm{~g})\end{array}$ & $\begin{array}{l}\text { Vitamin } \mathrm{B}_{2} \\
(\mathrm{mg} / 100 \mathrm{~g})\end{array}$ & $\begin{array}{l}\text { Vitamin C } \\
(\mathrm{mg} / 100 \mathrm{~g})\end{array}$ & $\begin{array}{l}\text { Vitamin E } \\
(\mathrm{mg} / 100 \mathrm{~g})\end{array}$ & B-Carotene (IU) \\
\hline $20 \mathrm{~g}$ & 0.7 & 5.25 & 26.25 & 22.50 & 500.00 \\
\hline $40 \mathrm{~g}$ & 0.7 & 3.75 & 26.88 & 24.50 & 444.45 \\
\hline $60 \mathrm{~g}$ & 1.0 & 0.75 & 29.37 & 27.0 & 722.23 \\
\hline Control & 0.6 & 2.25 & 4.00 & 24.0 & 466.68 \\
\hline LSD $(p<0.05)$ & 0.30 & 0.42 & 1.88 & 2.49 & 3.77 \\
\hline
\end{tabular}

The organoleptic scores of the formulated bread samples were shown in Table 5. The flavour of the formulated breads containing $60 \mathrm{~g}$ and $40 \mathrm{~g}$ were the most desirable with the sensory scores of 9.0. The organoleptic parameters scores of the formulated bread sample containing $60 \mathrm{~g}$ were statistically $(p<0.05)$ higher than those of the control sample. Bread samples containing $60 \mathrm{~g}$ was therefore the most preferred of all the samples with the score of 9.0 for colour, aftertaste and overall acceptability. Meanwhile, the main quality factors for bread are the colour, taste and mouth feel (Fellows, 1997).

Table 5:-The Effect of the M. oleifera pod Flours on the Organoleptic Properties of the Formulated Bread

\begin{tabular}{|l|l|l|l|l|l|}
\hline Samples & Colour & Flavour & Mouth feel & Aftertaste & $\begin{array}{l}\text { Overall } \\
\text { Acceptability }\end{array}$ \\
\hline $20 \mathrm{~g}$ & 6.0 & 6.0 & 8.0 & 7.0 & 6.0 \\
\hline
\end{tabular}




\begin{tabular}{|l|l|l|l|l|l|}
\hline $40 \mathrm{~g}$ & 9.0 & 9.0 & 8.0 & 8.0 & 8.0 \\
\hline $60 \mathrm{~g}$ & 9.0 & 9.0 & 9.0 & 9.0 & 9.0 \\
\hline Control & 5.0 & 4.0 & 7.0 & 6.0 & 4.0 \\
\hline LSD $(\mathrm{p}<0.05)$ & 2.49 & 2.50 & 2.98 & 2.49 & 2.50 \\
\hline
\end{tabular}

Values are mean of replicate treatment samples

\section{Conclusion:-}

The results of this study have shown that high nutrient containing breads could be developed from fortification of composite bread with Moringa oleifera pod flour. The breads contained reasonable amounts of macro-elements and trace elements that would be highly beneficial to human body. The Moringa oleifera pod flour also incorporated considerable amounts of medicinal phytochemicals into the bread at non-toxic levels for consumption. It is therefore evident that breads fortified with $M$. oleifera pod flour have great potentials of reducing food insecurity and malnutrition as well as providing prophylactic actions for the consumers, especially in developing nations. Fortification of composite breads with $60 \mathrm{~g}$ of $M$. oleifera pod flour for commercial consumption by both urban and rural dwellers, who eat bread daily, is highly recommended by this research.

\section{Reference:-}

1. American Society of Hematology (2019). Helping hematologists conquer blood disease worldwide. www.hematology.org

2. Anwar, F., Latif, S., Ashraf, M. \& Gilani, A. H. (2007). Moringa oleifera: a food plant with multiple medicinal uses. Phytother Res PTR. 21:17-25.

3. AOAC (2000). Association of Official Analytical Chemists. Official methods of analysis. Washington D. C. pp 220-224.

4. Aslam, M., Anwar, F., Nadeem, R., Rashid, U., Kazi, T. G. \& Nadeem, M. (2005). Mineral composition of Moringa oleifera leaves and pods from different regions of Punjab, Pakistan. Asian Journal of Plant Sciences. 4 (4) 417-421.

5. Awaziem, N. (2007). Physicochemical, Sensory Qualities and Storage Stabilities of Locally Produced Yoghurt in Enugu Metropolis. A B.Sc Project, Department of Food Science and Technology, UNN.

6. Botella, J. A., Ulschmid, J. K., Gruenewald, C., Moehle, C., Kretzschmar, D., Becker, K., \& Schneuwly, S. (2004). The Drosophila carbonyl reductase sniffer prevents oxidative stress-induced neurodegeneration. Current Biology, 14 (9), $782-786$.

7. Campbell, G. M. Herrero-Sanchez, R., Payo-Rodriguez, R. and Merchan, M. L. (2001). Measurement of dynamic dough density and effect of surfactants and flour type on aeration during mixing and gas retention during proofing, Cereal Chem., 78 (3) 272-277.

8. Collins, J. F., Prohaska, J. R. \& Knutson, M. D. (2010). Metabolic crossroads of iron and copper. Nutr Rev. 68 (3):133-147

9. David M. O. (2006). Nigeria No. 1 Market for U.S. wheat: Potential for other grains and seeds. Foreign Agric. Serv. Bull. pp. 1-2.

10. Dewettinck, K., Bockstaele, V., Kuhne, F., Van de Walle, B., Courtens, T. \& Gellynck, X (2008). Nutritional value of bread: Influence of processing, food interaction and consumer perception. Rev. J. Cereal sci., 48: 243257.

11. Dietary Guidelines for Americans (2010). U. S. Department of Agriculture, U.S. Department of Health and Human Services.

12. Egwim, E. C. Elem, R. C. \& Egwuche, R. U. (2011). Proximate composition, phytochemical screening and antioxidant activity of ten selected wild edible Nigeria mushrooms. American Journal of Food and Nutrition 1 (2): 89-94.

13. El-Ghorab, Ahmed Hassan, Muhammad Nauman, Faqir Muhammad Anjum, Shahzad Hussain, \& Muhammad Nadeem. 2010. "A comparative study on chemical composition and antioxidant activity of ginger (Zingiber officinale) and cumin (Cuminum cyminum)." Journal of agricultural and food chemistry 58 (14): 8231-8237.

14. Eze, E. I. \& Orjioke, C. (2010). Phytochemical and antimicrobial activities of Physcia grisea on clinical isolate of Salmonella typhi. Journal of Medical and Applied Biosciences. Vol 2, 93-98.

15. Finley, J. H. \& Phillips, R. O. (1989). Protein quality and the effects of processing. New York: M. Dekker. p. See Figure 2. ISBN 0-8247-7984-3.

16. Genstat Release 10.3DE (2011). VSN International ltd. (Rothamsted Experimental Station). 
17. Hamelman, J. (2004). Bread: a baker's book of techniques and recipes. New York: John Wiley. pp. 7-13. ISBN 0-471-16857-2.

18. Healthy Water Living (2007). BBC. Retrieved 2007-02-01. Archived from the original on 2007-01-01.

19. Hettiarachichi, M. Liyanage, C., Wickremasingle, R., Hilmers, D. C. \& Abrahams, S. A. (2006). Prevalence and severity of micronutrient deficiency: a cross-sectional study among adolescents in SriLanka. Asia Pac J. Clin Nutr. 15 (1) 56-63.

20. Hischenhuber, C., Crevel, R., Jarry, B., Mäki, M., Moneret-Vautrin, D. A., Romano, A., Troncone, R. \& Ward, R. (2006). Review article: safe amounts of gluten for patients with wheat allergy or coeliac disease. Aliment Pharmacol Ther. 23 (5): 559-75.

21. Huang, E. S., Brown, S. E., Ewigman, B. G., Foley, E. C. \& Meltzer, D. O. (2007). Patient Perceptions of Quality of Life with Diabetes-Related Complications and Treatments. Diabetes Care. 30 (10): 2478-83.

22. Ihekoronye, A. I. \& Ngoddy, P. O. (1985). Integrated Food Science for the Tropic. Macmilan Publishers, United Kingdom. Pp 50-128.

23. Iwe, M. O. (2002). Handbook of Sensory Methods and Analysis. Rojoint Communication Services Ltd., Enugu Nigeria.

24. Jakkutowicz, K., Tomick, Z. I., \& Leokadia, L. (1977). Determination of total plasma tocopherol in the presence of carotenes. Pol. Arch water. 20: 45-57.

25. Kalibbala, H. M., Wahlberg, O. \& Hawumba, T. J. ( 2009). "The impact of Moringa oleifera as a coagulant aid on the removal of trihalomethane (THM) precursors and iron from drinking water". Water Science and Technology: Water Supply. 9 (6): 707-714.

26. Mbaeyi, I. E. \& Anyanwu, L. N. (2010). Production and evaluation of yoghurt flavoured with solar-dried bush mango (Irvingia gabonensis) pulp. Journal of Tropical Agriculture, Food, Environment and Extension. 9: 137146.

27. National Heart, Lung, and Blood Institute (2019). U.S. Department of Health \& Human Services.www.nhlbi.nih.gov.health-topics.

28. Okonwu, K. \& Ugiomoh, I. G. (2015). Tannin contents of some economic plants in Nigeria. Journal of Plant Sciences. 10 (4) 159-166. DOI103923/jps2015.159.166.

29. Okwulehie, I. C. \& Odunze, E. T. (2004). Evaluation of the myco-chemical and mineral composition of some tropical edible mushroom. Journal of Sustainable Agriculture and Environment. 6: 63-70.

30. Olokodona, F. A., (2005). Analysis of fruit drinks and fruit juices. IPAN news vol 6 No.2 IPAN news vol 6 No.24, ISSN1595-3513.

31. Onwuka, G. I. (2005). Food Analysis and Instrumentation theory and practice. Naphthali Prints Lagos, Nigeria pp $142-143$.

32. Pietta P. G. (2000). Flavonoids as antioxidants. Journal of Natural Products. 63: 1035-1042.

33. Srinath, R. K.\&Katan, M. B. (2004). Diet, nutrition, and the prevention of hypertension and cardiovascular diseases. PublicHealth Nutr. 7 (1):167-186.

34. Stanley H.O, Umolo, E.A \& Stanley, C. N. (2011). Cultivation of oyster mushroom (Pleurotus pulmonarius) on amended corncob substrate. Agriculture and Biology Journal of North America. 2 (10): 1336-1339.

35. Tenbergen, K. (1999). Dough and Bread Conditioners. Food and Product Design Magazine. Retrieved 2 October 2016.

36. Touyz, R. M. (2003). Role of magnesium in the pathogenesis of hypertension. Molecular Aspects of Medicine. 24: $107-136$.

37. Tsao, R. (2010). Chemistry and biochemistry of dietary polyphenol. Journal of Nutrients. 2 (12): 1231-1246. 